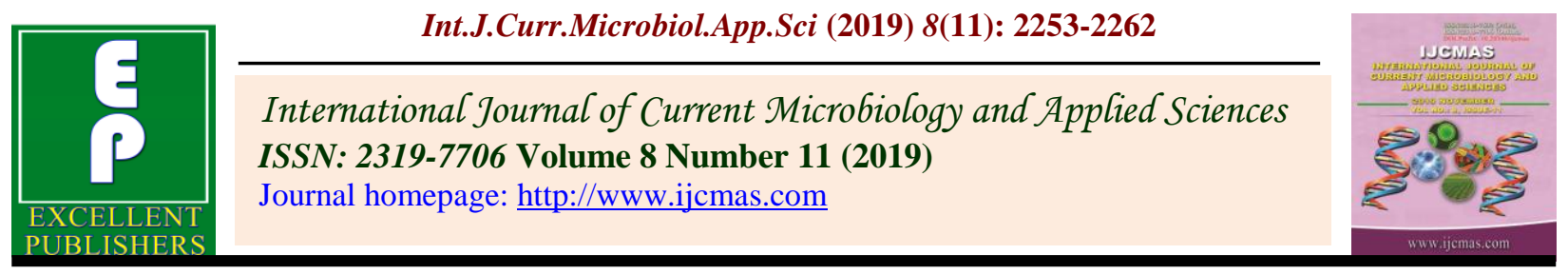

Case Study

https://doi.org/10.20546/ijcmas.2019.811.262

\title{
Economic Feasibility Analysis of North Western Himalayan Valley: A Case Study of Peach (Pruns persica)
}

\author{
Pardeep Singh*, Manoj K. Vaidya, Smriti Bansal, Ravinder Sharma \\ and Chandresh Guleria \\ Department of Social Sciences, Dr. Yashwant Singh Parmar University of Horticulture and \\ Forestry Nauni, Solan (H.P)-173230, India \\ *Corresponding author
}

\begin{tabular}{|l|}
\hline Ke y w o r d s \\
Cost, Return, \\
Feasibility, Present \\
Value and \\
Amortization \\
\hline Article Info \\
\hline Accepted: \\
22 October 2019 \\
Available Online: \\
10 November 2019
\end{tabular}

\section{A B S T R A C T}

Peach is one of the most important stone fruit in Zone II of North Western Himalayan valley. Peach cultivating farmers was selected using multistage random sampling techniques. The production constraints and economics of peach (Prunus persica (L) Batsch.) cultivation in Himachal Pradesh have been analysed. Results revealed that the economic productive life of peach orchards has been taken up to 20 years. The internal rate of return (IRR), Modified internal rate of return, net present value, benefit-cost ratio and payback period at 12 per cent discount rate have been worked out to be 20.54 per cent, 16.00 per cent, Rs 73827.58, 1.34 and 9 years, respectively. The results also revealed that the peach orchards are worth retaining as long as they give the income of about Rs 9762 over the annual maintenance cost. The economic appraisal of investment methods has indicated that annual amortization method may be preferred, because of its simplicity, efficiency and close to real situation results. To achieve the targets of fruits production, priority should be given to proper post-harvest management, including establishment of mechanical grading, packaging, on-farm processing, cold storage and quality control measures to minimize post-harvest losses and provide remunerative prices to the peach growers.

\section{Introduction}

India is the second largest producer of fruits in the world. Country has made good progress in fruit production with a total production of 97358 thousand MT from an area of 6506 thousand ha in 2018 (NHB 2018). Horticulture sector has a significant impact on the growth of the country's economy and it is expected that in future also it can make significant contribution towards accelerating the agricultural growth and contribution in GDP.

Himachal Pradesh is known as the fruit bowl of the country, situated in the lap of aesthetic Himalayan mountains between $32^{\circ} 22^{\prime} 40^{\prime}$ ' $N$ and $33^{\circ} 12^{\prime} 40^{\prime} ' \mathrm{~N}$ latitude and $75^{\circ} 47^{\prime} 55^{\prime}{ }^{\prime} \mathrm{E}$ and $79^{\circ} 04^{\prime} 22^{\prime}$ 'E longitude. The altitude 
ranges from $350 \mathrm{~m}$ to $7000 \mathrm{~m}$ above mean sea level. The altitude and the direction of the mountain ranges and the nature of the soil have a direct bearing on the ecology and the local flora and fauna. The state is having the advantage of varied climate ranging from subtropical to dry temperate. Horticulture sector in the states has made remarkable contributions in the upliftment of the socioeconomic conditions of the farming community. The niche advantages for fruits cultivation in the past have been exploited by the growers, wherever natural conditions, socio-economic and institutional environment were favorable. The increase in area and productivity of fruit crops in the state has pushed up the total production manifold during last few decades and consequently the marketable surplus. The total fruit production in the state was reported 565.31 thousand MT from area of 230.85 thousand ha (NHB 2018).

The major fruits produced in the state are apple, peach, plum, apricot, nectarine and cherry. Stone fruits are mainly grown in mid hills of Zone-II of agro-climatic regions of Himachal Pradesh. Mid Hills of Himachal Pradesh consists of Palampur and Kangra Tehsil of Kangra district, Rampur Tehsil of Shimla district and parts of Mandi, Solan, Kullu, Chamba, Bilaspur and Sirmaur district.

The elevation ranges from 915-1523 metres msl. It occupies about 32 per cent of the total geographical area and about 37 per cent of the cultivated area of the state and is suitable for stone fruits (Peach, Plum, Apricot, Nectarine), Persimmon, Pear, Pomegranate, Pecan nut, Walnut, Kiwifruit and Strawberry.

The plum, peach and apricot accounted for $8.60,5.08$ and 3.66 thousand ha area respectively with production of $20.52,8.05$ and 5.17 thousand MT respectively. The stone fruits are the second major fruit crop in the state (NHB 2016b).
Peach (Prunus persica (L) Batsch.) is one of the most important stone fruits grown in Himachal Pradesh, Punjab, Haryana, Uttarakhand and the adjacent areas of Western Uttar Pradesh. The demand for stone fruits and their processed products has increased because of rise in health concerns and nutritional awareness in the recent past. The demand for these fruits is expected to improve further in near future.

Because of refreshing, health promoting, and delicious qualities of peach fruit is popular all over northern India. It is also a rich source of vitamin A, iron and proteins. The harvesting season of peach ranges from May to July.

Peach is generally consumed as fresh, however, delicious squash and other processed products could be prepared from its varieties, viz. July Elberta, Red Heavn, Sun Heavn, Early Giant and Gloe Heavn cultivated in the north western Himalayas. The peach kernel oil is utilized in manufacturing of a large number of cosmetics and pharmaceutical products. The growth potential in peach cultivation is highly exciting for agro-processing, development of value-added products and employment generation through entrepreneurship development in the rural areas. The present study was undertaken in Himachal Pradesh with the main objectives to work out the costs and returns from peach orchards, determine the profitability of peach cultivation through different investment appraisal methods.

\section{Materials and Methods}

The present study was undertaken during 2017 in the Zone II North Western Himalayan region of Himachal Pradesh being a major hub of peach crop in the state and known as peach valley in situated between $30.8500^{\circ}$ North latitude and $77.2994^{\circ}$ East longitude as shown in Figure 1. 
The climate in Sirmaur district is predominantly cool during winters and moderately warm during summers. The average temperature during summer varies between $19^{\circ} \mathrm{C}$ to $28^{\circ} \mathrm{C}$ and in winter $1^{\circ} \mathrm{C}$ to $10^{\circ} \mathrm{C}$. Monthly precipitation varies from 15 $\mathrm{mm}$ in November to $434 \mathrm{~mm}$ in August and average total precipitation is $1575 \mathrm{~mm}$.

A Multistage random sampling technique was used for the selection of the respondents. At first stage, Rajgarh block out of 6 developmental blocks in Sirmaur district was selected on the basis of maximum area under peach plantation. At second stage, a list of panchayats growing peach in Rajgarh block was prepared which comes to 15 panchayats, out of these 6 panchayats were selected randomly. It forms a belt of peach farmers including Bhanat, Bhuria, Neri Kotli, Thaina Basotri, Serjagas and Shallana panchyats. At third stage complete list of villages of selected six panchayats was prepared and 2 villages were selected randomly from each panchayat. At fourth stage, list of farmers growing peach was prepared and a sample of 5 respondents from each village was selected randomly, thus, 60 growers were ultimately selected for collecting data.

\section{Estimating returns and economic feasibility of investment in peach orchards}

The project evaluation techniques were used for analysing economic viability of investment in orchards (Gittinger, 1974). Besides the present value summation method commonly used, i.e. net present value, benefit-cost ratio, payback period and internal rate of return, the annual amortization method (George, 1974; Subrahmanyam and Mohandas, 1982; Lee et al., 1988; Gangwar and Singh 1998; Padmanaban and Ramasamy, 1999, Gangwar et al., 2005). The amortized establishment cost was be used as a guideline to take decision on replanting of peach orchards. The amortization formula used was:

$P=B \times \frac{i}{1-(1+i)^{-n}}$

where,

$\mathrm{P}=$ Amount of annual payment

$\mathrm{B}=$ Initial amount

$n=$ Number of year (life period of plantation)

$\mathrm{i}=$ Interest rate

Using the amortized establishment cost, one can work out the absolute profit expected in a year from the orchards by deducting amortized cost along with maintenance cost from gross returns. The investment criteria like benefitcost (B-C) ratio and capital value $(\mathrm{CV})$ of the orchard was derived as follows:

$\mathrm{BC}$ Ratio $=\frac{\mathrm{GR}}{\mathrm{AEC}+\mathrm{MC}}---(1)$

where,

$\mathrm{GR}=$ Annual gross return, per hectare

AEC $=$ Amortized establishment cost per hectare, and

$\mathrm{MC}=$ Maintenance cost per hectare

$\mathrm{CV}=[\mathrm{GR}-(\mathrm{AEC}+\mathrm{MC})] \mathrm{DAPV}---(2)$

where, $\mathrm{CV}$ is the net present value from amortized method, GR, AEC and MC are the same as in Equation (2) and DAPV is deferred annuity present value of $\operatorname{Re} 1$, which is obtained by multiplying the present value of Re 1 per annum for the (n-r) bearing years at an interest rate of ' $i$ ' by present value of $\operatorname{Re} 1$ for ' $r$ ' non-bearing years at an interest rate of ' $i$ ' where ' $n$ ' is the total life period of the plantation. 


\section{Modified internal rate of return (MIRR)}

There are many problems with IRR as criterion for project evaluation ${ }^{5 \& 2}$. Some of which are:

The IRR method can lead to erroneous rankings of the mutually exclusive projects when compared to net present value (NPV) method of capital budgeting.

The IRR method assumes that the future cash flows will be reinvested and get the returns equal to IRR.

In literature, Modified Internal rate of return (MIRR) method of capital budgeting has been used to take care of the problems arising out of reinvestment assumption. When scale or time span differences exist, the MIRR method give ranking of mutually exclusive projects that are different than of NPV. Hence, IRR needs adjustments to take care of these problems (Guleria et al., 2017)

$$
M I R R=\sqrt[n]{\frac{F V(\text { Positive ca } \square \text { flows })}{-P V(\text { Negative cas } \square \text { flows })}-1}
$$

where $n$ is the number of equal periods at the end of which the cash flows occur (not the number of cash flows), $P V$ is present value (at the beginning of the first period), $F V$ is future value (at the end of the last period).

\section{Results and Discussion}

The age-wise costs and returns from peach were calculated on the basis of annual cash inflow and cash outflows. The data on the cost of cultivation of agricultural commodities is useful for planning as these data inform the planners about the area where it is economical to produce various commodities and the regions which would be accordingly most suitable for the development of industries based on the agricultural raw material.

At the micro level, it enables the farm management experts to study the efficiency of the various cultivation practices and alter the crop planning by providing information regarding their profitability. This helps the experts to make practical recommendations for farm planning aimed at better allocation of existing resources and introduction of agronomic practices which would further increase the efficiency of crop production.

Cost structure, output and return from peach in the study area has been discussed under cost of initial plantation and cost in maintaining the plantation during non-bearing stage and during bearing stage of plants. The summation of cost incurred during plantation (initial investment) and costs during non-bearing stage is termed as establishment cost which is distributed over total productive life of the plantation.

The cost and return were worked out on hundred plant basis for estimating the cost and returns with the realistic assumption that,

First bearing start from $6^{\text {th }}$ year onward, the major operation and input requirement remains same in 6-10, 11-15 and 16-20 year age groups of plants and the total economic life of plantation is 20 years. The above mentioned groups are based on the physiological growth and productivity pattern of the plant.

\section{Cost of plantation (initial investment)}

The item wise plantation cost incurred in the initial year is presented in Table 1. It is clear from the table that, peach orchardists in study area incurred on an average, a total cost of Rs. 19341.30 per hundred plants, at the initial stage. Material inputs averaged nearly 37.49 
per cent and cost incurred on labour investment was around 26.27 per cent of the total cost. The major portion of labour is from own farm workforce. Managerial cost and risk margin each accounted for 4.09 per cent of the total cost. Rental value of land shared 21.43 per cent of the total initial investment cost.

\section{Cost during non-bearing stage of peach plantation}

The total maintenance cost during non-bearing peach plantation has shown positive relationship with age of the plants and was ranged between Rs. 17239.20 to Rs. 26413.60 from first to fifth year. The per cent share of variable cost in the total maintenance gradually decreased with the age of plantation and remain more than 50 per cent in all the years, however, the absolute expenditure is increasing with increase in the size of the plants. Total fixed cost per cent share in the total maintenance cost was increasing with increasing in the age of plants and major component in fixed was interest on past establishment cost which will ultimately recovered during the economic bearing life of plantation.

\section{Cost during bearing stage of peach plantation}

Total productive life of peach plants has been divided in three age groups, considered relatively homogenous with respect to productivity and input use etc. The establishment cost has been spread over 20 years of bearing life on prorated basis using interest rate of 8 per cent. Similar to the situation where total establishment cost is assumed to have been borrowed at 8 per cent of interest rate and prorated figure presents the value of installment to fully repay the amount in 20 years. The data reveals that increase in total cost in the early years of plantation was calculated to Rs. 36706.40 and Rs. 39101.30 per hundred plants in the age groups of 6-10 and 11-15 years respectively and then gradually decreased to Rs. 38209.00 in the age group of 16-20 years of age. In the initial years of development stage of the plants the labour and material inputs were increasing with the growth of the plants up to the maturity in the age group of 11-15 years, after which the productivity of peach plants start decreasing.

The labour use increased tremendously during the peak period of productivity phase i.e. in the age group of 11-15 years as compared to early phase of fruiting and decreased in the later age group of 16-20 years. This has been due to the peach plant after attained the full maturity in the age of 15 years, showed a decrease in production and thus the labour for harvesting started decreasing. The share of labour in total cost of production varied between 16.87 to 17.06 per cent in the various age groups. The total material costs were found 26.69 to 29.16 per cent of total costs in the age group of 6-10 to 11-15 years respectively and then gradually decreased to 28.41 per cent in the age group of 16-20 years at overall farm categories. The result indicates that peach orchards would need replantation after 20 years as the economic productive life of peach orchards was up to 20 years in the study area

\section{Cash flow statement of peach cultivation}

The average return in term of money value was highest in the age group of 11-15 year i.e. Rs. 94906.00 followed by age group of 16-20 year Rs. 85238.42 and age group of 6-10 year Rs. 76782.64. The average gross return of peach was worked out to Rs. 85642.35 (Table 2 ). The average cost and gross and net returns from peach orchards have been presented in Table 3. 
Table.1 Costs of peach plantation in the study area

\begin{tabular}{|c|c|c|c|c|c|c|c|c|c|c|}
\hline \multirow{3}{*}{$\begin{array}{c} \\
\text { SI } \\
\text { No. }\end{array}$} & \multirow{3}{*}{ Particulars } & \multirow{3}{*}{\begin{tabular}{r|} 
Initial \\
investment \\
year $)$
\end{tabular}} & \multirow{2}{*}{\multicolumn{5}{|c|}{ Non bearing }} & \multicolumn{3}{|c|}{ (Per cent) } \\
\hline & & & & & & & & & Bearing & \\
\hline & & & $1^{\text {st }}$ year & $2^{\text {nd }}$ year & $3^{\text {rd }}$ year & $4^{\text {th }}$ year & $5^{\text {th }}$ year & 6-10 year & 11-15 year & 16-20 year \\
\hline 1 & \multicolumn{10}{|c|}{ Material Cost } \\
\hline i) & $\begin{array}{l}\text { planting material/Gap } \\
\text { filling }\end{array}$ & 25.87 & 1.48 & - & - & - & - & - & - & - \\
\hline ii) & Bordeaux mixture & - & 0.75 & 0.79 & 0.84 & 0.83 & 0.83 & 0.72 & 0.74 & 0.74 \\
\hline iii) & Lime & - & 0.25 & 0.24 & 0.23 & 0.22 & 0.21 & 0.18 & 0.18 & 0.18 \\
\hline iv) & FYM cost & 10.53 & 20.41 & 19.24 & 17.74 & 16.34 & 15.24 & 15.73 & 15.83 & 15.77 \\
\hline v) & Fertilizer cost & - & 4.16 & 4.88 & 6.15 & 6.93 & 7.38 & 8.29 & 10.43 & 9.76 \\
\hline vi) & $\begin{array}{l}\text { Plant protection (soil } \\
\text { treatment, pesticide) }\end{array}$ & 1.09 & 1.33 & 1.28 & 1.18 & 1.13 & 1.08 & 1.23 & 1.37 & 1.38 \\
\hline \multirow[t]{2}{*}{ vii) } & Insecticide & - & 0.57 & 0.58 & 0.58 & 0.55 & 0.56 & 0.54 & 0.62 & 0.59 \\
\hline & Sub total & 37.49 & 28.94 & 27.01 & 26.72 & 26 & 25.29 & 26.69 & 29.16 & 28.41 \\
\hline 2 & Family labour cost & 22.9 & 24.2 & 22.7 & 20.79 & 19.14 & 17.66 & 14.28 & 14.06 & 14.2 \\
\hline \multirow[t]{2}{*}{3} & Hired labour cost & 3.37 & 1.1 & 1.13 & 0.98 & 1.01 & 0.97 & 2.77 & 2.9 & 2.67 \\
\hline & Sub total & 26.27 & 25.31 & 23.83 & 21.77 & 20.15 & 18.63 & 17.06 & 16.96 & 16.87 \\
\hline 4 & Interest on working capital & 1.84 & 1.35 & 1.27 & 1.25 & 1.22 & 1.18 & 1.33 & 1.44 & 1.4 \\
\hline 5 & Risk Margin & 4.09 & 3 & 2.81 & 2.77 & 2.7 & 2.63 & 2.95 & 3.21 & 3.11 \\
\hline \multirow[t]{2}{*}{6} & Managerial cost & 4.09 & 3 & 2.81 & 2.77 & 2.7 & 2.63 & 2.95 & 3.21 & 3.11 \\
\hline & Sub total & 10.01 & 7.36 & 6.89 & 6.79 & 6.62 & 6.43 & 7.22 & 7.85 & 7.62 \\
\hline 7 & Total Variable Cost & 73.77 & 61.61 & 57.73 & 55.28 & 52.77 & 50.36 & 50.97 & 53.97 & 52.9 \\
\hline 8 & \multicolumn{10}{|c|}{ Fixed cost } \\
\hline i) & Land revenue & 0.03 & 0.03 & 0.03 & 0.03 & 0.03 & 0.02 & 0.02 & 0.02 & 0.02 \\
\hline ii) & Depreciation & 3.59 & 4.04 & 3.68 & 3.27 & 2.93 & 2.63 & 1.9 & 1.78 & 1.82 \\
\hline iii) & Interest on Fixed capital & 1.18 & 1.33 & 1.21 & 1.08 & 0.96 & 0.87 & 0.62 & 0.59 & 0.6 \\
\hline iv) & Rental value of land & 21.43 & 24.02 & 21.88 & 19.47 & 17.44 & 15.67 & 11.28 & 10.59 & 10.84 \\
\hline v) & $\begin{array}{c}\text { Interest on past } \\
\text { establishment cost }\end{array}$ & - & 8.98 & 15.47 & 20.88 & 25.87 & 30.44 & - & - & - \\
\hline vi) & $\begin{array}{l}\text { Pro-rated establishment } \\
\text { cost @ } 8 \text { per cent }\end{array}$ & - & - & - & - & - & - & 35.22 & 33.06 & 33.83 \\
\hline 9 & Total fixed cost & 26.23 & 38.39 & 42.37 & 44.72 & 47.23 & 49.64 & 49.03 & 46.03 & 47.1 \\
\hline \multirow[t]{2}{*}{10} & \multirow[t]{2}{*}{ Total cost (Rs.) } & 100.00 & 100.00 & 100.00 & 100.00 & 100.00 & 100.00 & 100.00 & 100.00 & 100.00 \\
\hline & & (19341.30) & $(17239.20)$ & (18921.00) & $(21266.80)$ & (23740.10) & $(26414.60)$ & (36706.40) & (39101.30) & $(38209.00)$ \\
\hline
\end{tabular}

Figure in parentheses indicate total initial cost in Rs.

Table.2 Gross return from different age groups of peach

(Rupees)

\begin{tabular}{|c|c|c|}
\hline Age groups & Cash outflows & Cash Inflows \\
\hline $\mathbf{6}^{\text {th }}-\mathbf{- 1 0}^{\text {th }}$ year & 36706.40 & 76782.64 \\
\hline $\mathbf{1 1}^{\text {th }}-\mathbf{1 5}^{\text {th }}$ year & 39101.30 & 94906.00 \\
\hline $\mathbf{1 6}^{\text {th }}-\mathbf{2 0}^{\text {th }}$ year & 38209.00 & 85238.42 \\
\hline Average cash outflows and inflows & 38005.57 & 85642.35 \\
\hline
\end{tabular}


Fig.1 Net present worth Sensitivity analysis for peach cultivation

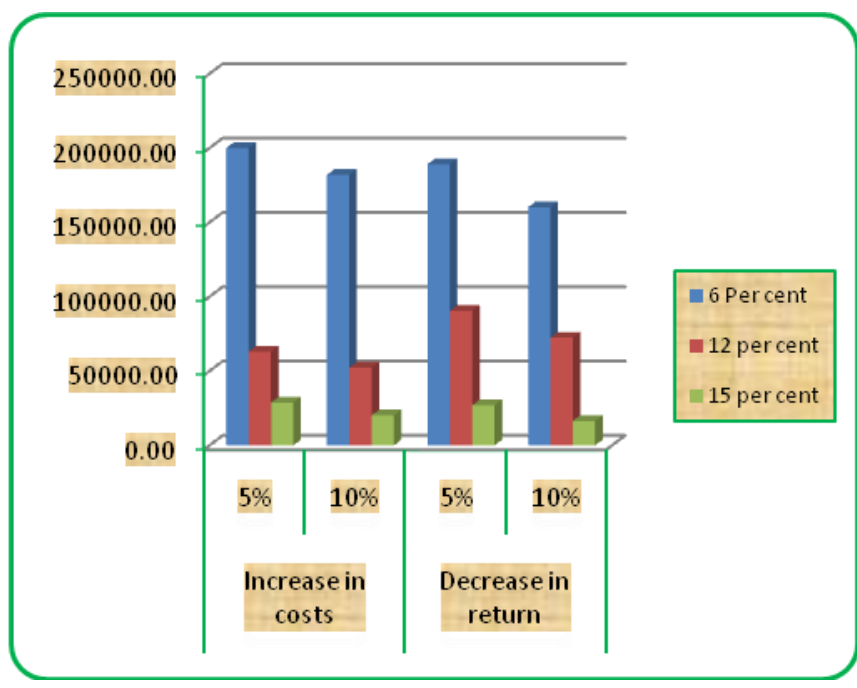

Fig.3 Benefit Cost Ratio Sensitivity analysis for peach cultivation

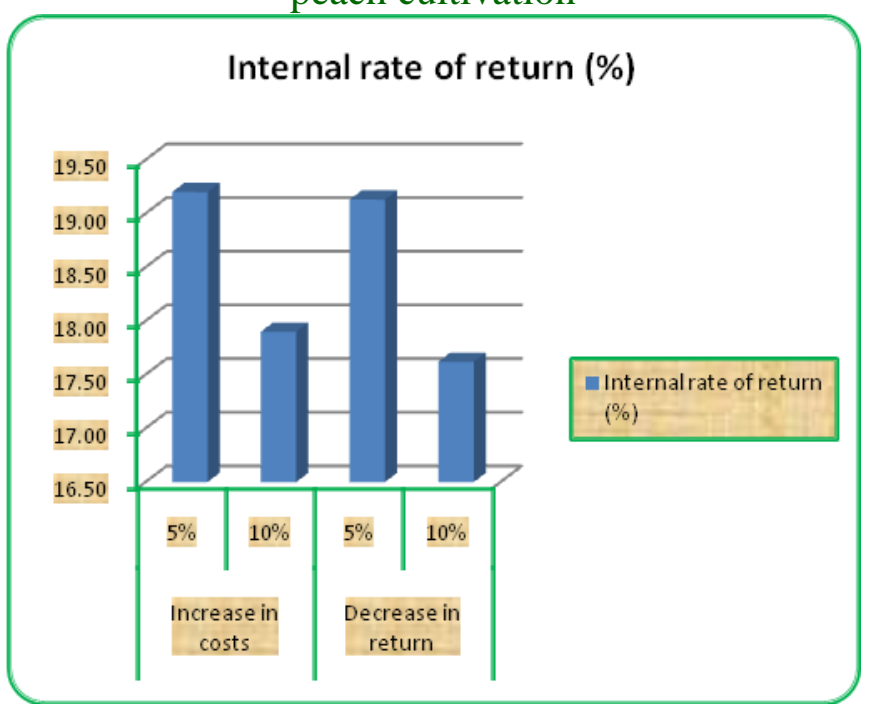

Fig.2 Benefit Cost Ratio Sensitivity analysis for peach cultivation

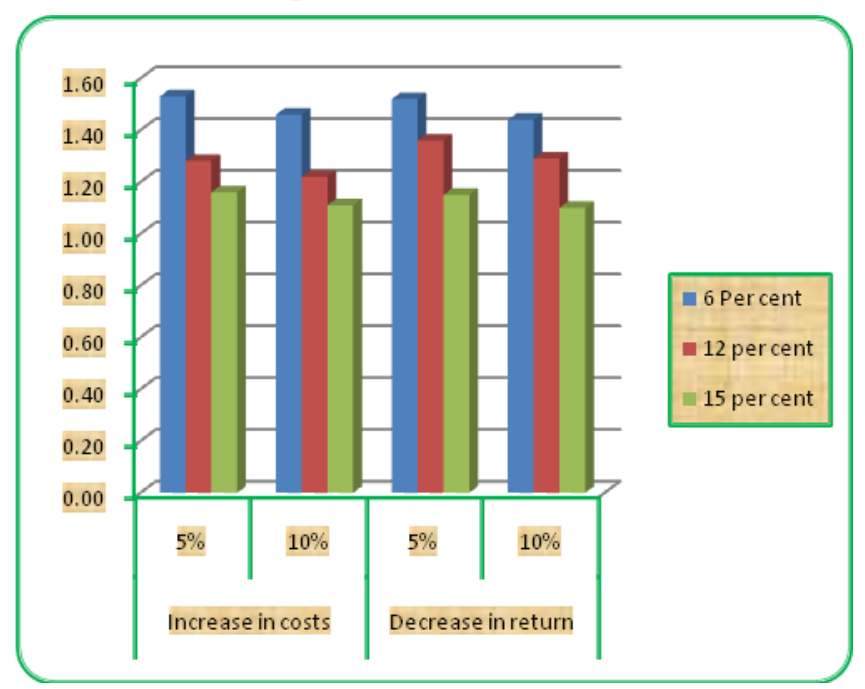

Fig.4 Modified internal rate of return Sensitivity analysis for peach cultivation

\section{Modified internal rate of return (\%)}

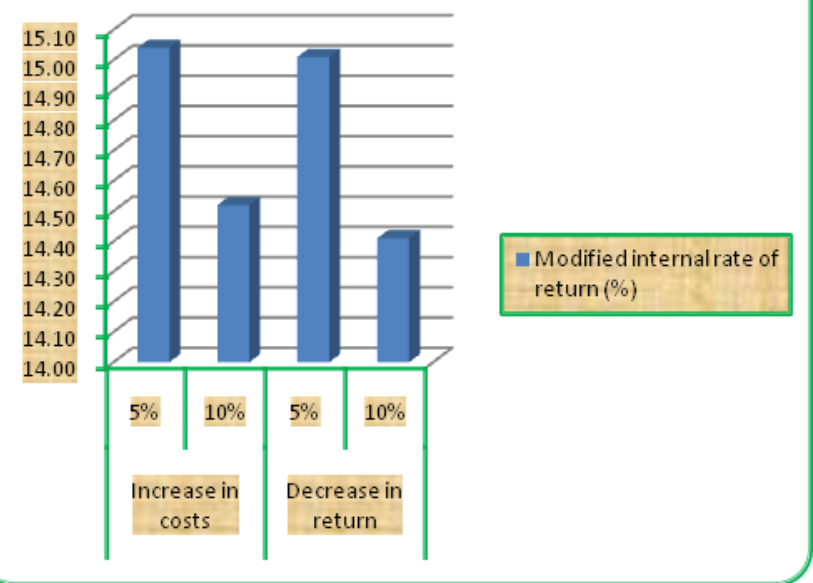

Table.3 Average costs and return from peach orchards

\begin{tabular}{|c|c|c|}
\hline SI No. & Particulars & Amount \\
\hline $\mathbf{1}$ & Establishment cost amortized over 20 years @ 12 per cent per year & 16784.04 \\
\hline $\mathbf{2}$ & Average maintenance cost & 38005.57 \\
\hline $\mathbf{3}$ & Total cost per year & 54789.61 \\
\hline $\mathbf{4}$ & Average gross income per year & 85642.35 \\
\hline $\mathbf{5}$ & Net income per year & 30852.74 \\
\hline
\end{tabular}


Table.4 A comparison of two methods of investment worth per 100 plants of peach

\begin{tabular}{|c|c|c|}
\hline Measures of investment worth & $\begin{array}{c}\text { Present value } \\
\text { method }\end{array}$ & $\begin{array}{c}\text { Amortization } \\
\text { Method }\end{array}$ \\
\hline Net Present Value & 73827.58 & 43477.14 \\
\hline Benefit cost ratio & 1.34 & 1.12 \\
\hline Annuity (Uniform annual return) & 9762.97 & 6383.50 \\
\hline Pay Back Period (years) & 9.00 & - \\
\hline Internal Rate of Return (\%) & 20.54 & - \\
\hline Modified Internal Rate of Return (\%) & 16.00 & - \\
\hline
\end{tabular}

It shows that the net returns over maintenance cost and over total cost were Rs 47636.78 and Rs 30852.74 respectively. The ratio of returns to maintenance cost worked out to be 2.25 for peach orchards.

\section{Financial feasibility of peach plantation}

The principal objective of any plantation programme is to increase the productivity of land, to meet the basic requirements of rural population, to create employment opportunities in general and to promote socioeconomic prosperity.

The discounted and amortized values of returns were calculated at the rate of 12 per cent, because the financial institutions advance short-term loan to the peach growers/farmers at this rate of interest. A perusal of Table 4 revealed that the payback period was found 9 years (similar results were showed by Gangwar et al., 2008). The NPV worked out to be Rs 73827.58 , the benefit-cost ratio as 1.34 and internal rate of return (IRR) as 20.54 per cent under the present value summation method. Under the amortization method also, the NPV and B-C ratio were similarly at Rs 43477.14 and 1.12, respectively. Both these measures clearly indicated that peach cultivation in Himachal Pradesh was a profitable venture. Peach cultivation could be a vital alternative for crop diversification endeavors, if infrastructure facilities were developed for scientific post-harvest handling, storage, packaging, transportation and marketing.

A comparison of the results obtained from the two appraisal methods revealed that the amortization method had underestimated the benefit-cost (B-C) ratio and present (capital) value of the peach orchard; however, the difference in B-C ratios was large (Table 4). There was a wide difference in income calculated under present value method and amortization method. The amortization method suggested an income of more than Rs $6,383.50$ over the maintenance cost for retaining the peach orchards, as this income was enough to meet amortized establishment cost. The present value method required an income of more than Rs 9762.97 for retaining the old peach orchards.

\section{Sensitivity analysis}

The rate of return from investment is likely to change according to changes in basic parameters, such as future yield, input and output prices and demand estimates. It is quite possible that when the area under peach plantation is increased, the supply of final product also increases. This will have an adverse effect on prices and income of the producers. It is therefore, important to examine the sensitivity of the benefit cost returns to change in costs and returns caused by changes in assumptions about prices and yields. 
The sensitivity analysis for peach production is based on two assumptions:

Cash outflows of peach increased by 5 per cent and 10 per cent with constant returns.

Returns decreased by 5 per cent and 10 per with constant cost.

The sensitivity analysis of peach plantations has been presented in Figure 2-4. The sensitivity analysis of peach plantations showed that an increase of 5 to 10 per cent in cost does not make the cultivation uneconomic as economic measures are well in the range with small change in their magnitudes. Similarly a decrease of 5 to 10 per cent in returns does not affect the economic feasibility. Net present value ranged between Rs. 16440.37 to Rs. 200052.40, Benefit cost ratio ranged between 1.10 to 1.53 and IRR varied from 17.62 to 19.20 per cent at discount rates 6,10 and 15 per cent. Hence investment in peach proves to be stable with changes in cost and yield variations (similar representation of sensitivity analysis was used by Guleria et al., 2017).

The study has revealed that investment in peach orchards is economically profitable venture, financially viable and socially acceptable business in Himachal Pradesh. This study concluded that peach becomes one of the crop for raising the income of the farmers in mid hill zone as apple does in the high hill temperate zone of Himachal Pradesh. It could play a vital role in strengthening the on-farm primary processing-based agro-industry and generate employment opportunities through entrepreneurship development, to meet the demand of fresh and processed peach products in the domestic markets. Excluding the rental value of land (opportunity cost), investment in peach orchards has a pay-back period of eight years. The economic productive life of peach orchards was approximately 20 years. The orchards need to be replanted when the annual (net) returns over maintenance cost falls below Rs 19341.30, for the orchard per hundred plants. The comparison of results obtained from the present value method and amortization method has shown that the peach plantations are worth retaining as long as they give an income of Rs 9762.97 over the maintenance cost. Regarding the method of economic appraisal of investment in peach orchards, the annual amortization method may be preferred (over the present value summation method) because of its simplicity, equal efficiency and close to real situation results. To enhance peach production in the study area, there is a need to develop infrastructural facilities to reduce post-harvest losses and value addition through on-farm primary processing at the peach orchards level.

\section{References}

Gittinger, J.P. (1974) Economic Analysis of Agricultural Projects. Economic Development Institute, International Bank for Reconstruction and Development, Washington. D.C., USA.

George, P.S. (1974) Nagpur oranges: A micro study on agribusiness system. CMA Monograph No.16, Indian Institute of Management, Ahmedabad.

Subrahmanyam, K.V. and Mohandas, V. (1982) Economic evaluation of coorg mandarin orange in Karnataka. Indian Journal of Agricultural Economics, 37(1): 70- 76.

Lee, Warren F., Woehlje, M.D., Nelson, A.G. and Murray, W.G. (1988) Agricultural Finance. First Indian Edition, Kalyani Publishers, New Delhi.

Gangwar, L.S. and Singh, Shyam (1998) Economic evaluation of Nagpur mandarin cultivation in Vidarbha region of Maharashtra. Indian Journal 
of Agricultural Economics, 53(4): 648653.

Padmanaban, N.R. and Ramasamy, C. (1999) Economic appraisal of eucalyptus under agro-forestry in Tamil Nadu. Agricultural Situation in India, 56(11): 671-673.

Gangwar, L.S., Ilyas, S.M., Singh, Dinesh and Kumar, Sandeep (2005) An economic evaluation of kinnow mandarin cultivation in Punjab. Agricultural Economics Research Review, 18(1): 71-80.

NHB (Indian Horticulture Database) (2018a) National Horticulture Board, Gurgaon, Haryana.
NHB (Indian Horticulture Database) (2018b) National Horticulture Board, Gurgaon, Haryana.

Gangwar L.S., Singh, D and Mandal, G. (2008) Economic Evaluation of Peach Cultivation in North Indian Plains. Agricultural Economics Research Review, 21: 123-129.

Guleria A., Tiwari P and Sharma R. (2017) Cost of Cultivation and Economic Feasibility of Grafted Harar (Terminalia chebula) in Himachal Pradesh. International Journal of Pure and Applied Biosciences, 5(2): 10051011.

\section{How to cite this article:}

Pardeep Singh, Manoj K. Vaidya, Smriti Bansal, Ravinder Sharma and Chandresh Guleria. 2019. Economic Feasibility Analysis of North Western Himalayan Valley: A Case Study of Peach (Pruns persica). Int.J.Curr.Microbiol.App.Sci. 8(11): 2253-2262.

doi: https://doi.org/10.20546/ijcmas.2019.811.262 